\title{
Effect of substrate change on macrozoobenthos structure
}

\author{
Daria Mimier, Janusz Żbikowski" \\ Department of Hydrobiology, Faculty of Biology and Environmental Protection, \\ Nicolaus Copernicus University Lwowska 1, 87-100 Toruń, Poland, \\ *e-mail: jzbikow@umk.pl
}

Received: 04 September 2017 / Accepted: 03 October 2017

\begin{abstract}
The aim of the study was to determine the impact of the increase in the organic matter content in the bottom sediments on the benthic fauna structure. The research was carried out in a strongly rheolimnic the Włocławek Dam Reservoir (Poland). The samples were taken on eight dates from March 1988 to February 1989. The sampling sites were located at the following depths: 1 $\mathrm{m}, 2 \mathrm{~m}, 5 \mathrm{~m}, 8 \mathrm{~m}$ and $10 \mathrm{~m}$.

The organic matter content in the bottom sediments increased with depth from $0.6 \%$ at a depth of $1 \mathrm{~m}$ to $13.2 \%$ at a $10 \mathrm{~m}$ depth. To a depth of $8 \mathrm{~m}$, the bottom fauna was relatively rich in quality. The significant decline in the diversity and, above all, the number of taxa of the macrozoobenthos groups, only at a depth of $10 \mathrm{~m}$ were found. In turn, the abundance (density and biomass) of the bottom fauna increased with depth of the site.

The analysis of the increase in Oligochaeta abundance with depth suggests that at the level of about $4 \%$ of the organic matter content in the bottom sediments, the food conditions are no longer a factor limiting the Oligochaeta occurrence.
\end{abstract}

Key words: benthic fauna, bottom sediments, abiotic environment, shore zone.

\section{Introduction}

Benthic macroinvertebrates play extremely important role in the functioning of aquatic ecosystems (Graneli, 1979; Wiśniewski \& Planter, 1985; Svensson \& Leonardson, 1996; dos Santos, 2016). Moreover, they can clearly reflect the ecological conditions of the aquatic ecosystems they inhabit (Callisto et al., 2005; Behrend et al., 2012). Due to their weak moving ability, the bottom fauna is a very good indicator reflecting also changes in an aquatic ecosystem (Moreno \& Callisto, 2006). Thus, identifying the spatial distribution of benthic macroinvertebrates allows determination of their responses to environmental gradients (Wills et al., 2006; Angradi et al., 2009; Pelletier et al., 2010).

The distribution of aquatic macroinvertebrate species and communities is controlled by a variety of environmental factors such as depth, water quality (Hellawell, 1986), substrate type (Reynoldson et al., 1995; Chapman et al., 1997), sediment grain size (Tolkamp, 1980), organic matter content in sediments (Rodriguez et al., 2001; Ciutat et al., 2006) or contaminants (Clements \& Kiffney, 1993; Phipps et al., 1995). The occurrence of macrophytes is also of great importance for macrozoobenthos (Hargeby et al., 1994; Scheffer, 1998; Declerck et al., 2005), as well as the presence of a "coarse" detritus (particle diameter $>480$ $\mu \mathrm{m}$ ) in sediments (Moss \& Timms, 1989; Kornijów et al., 1995; Merritt et al., 2002) which arise mainly from plant decomposition. Their impact relates, among other things, to improved nutritional and habitat conditions for macrozoobenthos. Because of the relationships and dependencies between all the above mentioned factors shaping the zoobenthos structure it is difficult to specify which one plays the most important role. According to many authors, the oxygen conditions near the bottom and the quality and 
availability of food are of the utmost importance (Siegfried, 1984; Cooper \& Knight, 1985; Rassmusen, 1988; Real \& Prat, 1991; Prat et al., 1992).

With the increase in the water depth significant decreases in the number of taxa and diversity and sometimes also in the abundance of bottom fauna are noted. It is difficult to identify the main cause of horizontal changes in the macrozoobenthos structure as the depth increase results in changes in many different above mentioned factors influencing this structure.

However, to some extent, such a possibility exists in the highly rheolimnic the Włocławek Dam Reservoir. The right shore zone of the reservoir is characterized by a high inclination angle of the bottom. Due to the high water dynamics in this part of the reservoir, resulting from the flow of Vistula river waters through the reservoir, the values of most of the abiotic water parameters, including those very important in shaping the bottom fauna structure, such as its oxygenation above the bottom, do not show significant differences despite the marked increase in depth except for the deepest site (Żbikowski, personal information). The only abiotic parameter showing significant horizontal changes, and at the same time important in shaping the macrozoobentos structure, is the substrate type. Namely, as the depth increases, there is an increase in the organic matter content in the bottom sediments. This provides an excellent opportunity to evaluate the impact of this parameter on macrozoobenthos structure.
The aim of this study is therefore to determine the impact of the increase in the organic matter content in the bottom sediments on the benthic fauna structure. We put forward the following working hypotheses: 1. the high water dynamics in the reservoir will allow a deeper occurrence of taxa considered to be typical for the littoral zone, sensitive to oxygen deficiency; 2 . the increase in the organic matter content at the bottom will result in the increase in the share of Oligochaeta in the total macrozoobenthos density.

\section{Study area}

The Włocławek Dam Reservoir (WDR) was created in 1970 and is situated between the 618th and the 675th kilometre of the Vistula river course (Fig. 1). It is the largest Polish reservoir with respect to surface area and the second largest considering volume, so the WDR is one of the greatest midland water bodies in Poland. The basic morphometric parameters of the WDR, according to Grześ (1983) are the following: surface area $75 \mathrm{~km}^{2}$, total volume $400 \mathrm{mln} \mathrm{m}^{3}$, usable volume $55 \mathrm{mln} \mathrm{m}^{3}$, mean width $1,210 \mathrm{~m}$ (range 500-2,500 m), mean depth $5 \mathrm{~m}$ (maximum $15 \mathrm{~m})$, mean water flow $900 \mathrm{~m}^{3} \mathrm{~s}^{-1}$.

The WDR is a strongly rheolimnic reservoir (run-offriver reservoir), of very elongated, riverine, channel-like shape, characterized by extremely short water residence

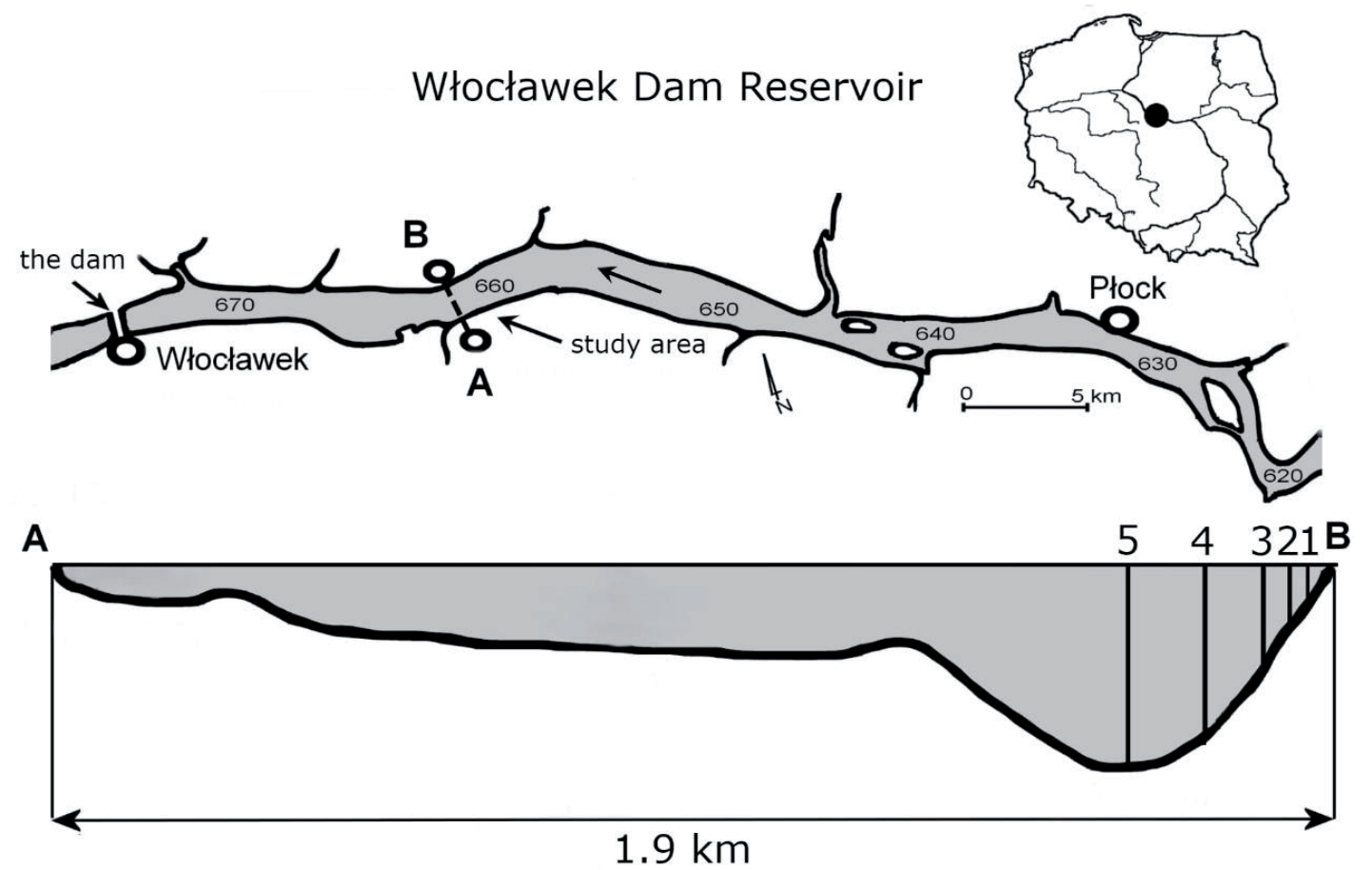

Figure 1. Location of the sampling stations in the Włocławek Dam Reservoir. 1, 2, 3, 4, 5 - sampling stations 
time (ca. 4-7 days). It is a highly eutrophic water body (Żytkowicz et al., 1990; Kentzer et al., 1999), but many negative consequences of the high trophic level are reduced by its hydrodynamic conditions, such as the high water flow rate and intensive wind mixing resulting from the large area and high exposure to the wind. For example, the lack of a strong, long-lasting thermal stratification results in relatively good oxygen conditions at the bottom of the reservoir. A very important factor, influencing the hydrological conditions in the reservoir, is its small usable volume (14\% of the total volume), resulting in low fluctuations of the water level - usually below $0.5 \mathrm{~m}$ (Żbikowski et al., 2007).

In the study area the shore of the WDR is high and steep. Below the water table there is a very short (about 2-3 m), shallow and sandy shore-platform after which the bottom drops rapidly to a maximum at this region depth of $10 \mathrm{~m}$ (Fig. 1). As already mentioned, the analyzed area is characterized by strong homogenisation of its environmental conditions. In addition, there are no macrophytes and "coarse" detritus particles in this zone.

\section{Materials and methods}

The samples were taken on eight dates: March 21th, April 25th, June 20th, July 28th, August 30th, September 22th, November 8th in 1988 and February 27th in 1989. The sampling sites were located at the following depths: $1 \mathrm{~m}$ (st. 1), 2 m (st. 2), $5 \mathrm{~m}$ (st. 3), $8 \mathrm{~m}$ (st. 4) and $10 \mathrm{~m}$ (st. 5) (Fig. 1). Site 1 was on the sandy shore platform, while sites 2 and 3 at the sandy-muddy very steep bottom, yet relatively close to the shore were located. Sites from 1 to 3 were originally on the land areas, flooded by the damming of water after the dam reservoir was built. In contrast, sites 4 and 5, with muddy bottom, were located in the former Vistula river bed, the latter approx. $100 \mathrm{~m}$ from the shore.

To collect the bottom fauna at depths of $1 \mathrm{~m}$ and $2 \mathrm{~m}$ a core sampler was used (catching area of $22.5 \mathrm{~cm}^{2}, 10$ pooled samples), whereas at the deeper sampling stations, due to a high abundance of the bottom fauna, a Kajak core sampler with the catching area of $40 \mathrm{~cm}^{2}(4-5$ pooled samples) was used. The samples were sieved through a $0.5 \mathrm{~mm}$ mesh size and the collected macrozoobenthos was preserved with $4 \%$ formaldehyde. To assess the fresh biomass of the benthic invertebrates, preserved animals were dried on blotting paper and weighed to the nearest $0.0001 \mathrm{~g}$ with an analytical scales PRL T A13 (Poland). The Chironomidae larvae were determined on the basis of Wiederholm (1983), while taxonomic identification of Mollusca was carried out using keys by Piechocki (1979) and Piechocki and Dyduch-Falniowska (1993). In order to assess the organic matter content in the bot- tom sediments, their surface layer $(0-5 \mathrm{~cm})$ was taken by means of Kajak core sampler with an area of $10 \mathrm{~cm}^{2}$. This parameter was measured by igniting dried sediments at $550^{\circ} \mathrm{C}$ for 2 hours.

\section{Results}

The organic matter content in the bottom sediments increased with depth. At a depth of $1 \mathrm{~m}$, it was $0.6 \%$, at a depth of $2 \mathrm{~m}-1.9 \%$, at a depth of $5 \mathrm{~m}-3.7 \%$, at a depth of $8 \mathrm{~m}-7.0 \%$ and at a depth of $10 \mathrm{~m}-13.2 \%$ of the dry mass of the sediments.

\section{Bottom fauna}

Over the course of the study 34 macrozoobenthos taxa were found (Table 1). The number of taxa was comparable at depths of $1 \mathrm{~m}$ to $8 \mathrm{~m}$ (range from 22 to 27) and clearly lower at a depth of $10 \mathrm{~m}$ (14 taxa). In turn, the diversity of benthic fauna (Shannon index) was similar (from 1.29 to 1.42 ) at depths of $1 \mathrm{~m}, 8 \mathrm{~m}$ and $10 \mathrm{~m}$ and higher than at depths of $2 \mathrm{~m}$ and $5 \mathrm{~m}(0.69 ; 0.94$, respectively).

The density of benthic fauna increased with depth. (Table 1). The rapid increase in this parameter occurred to a depth of $5 \mathrm{~m}$ (from 22 thous. ind. $\mathrm{m}^{-2}$ to 81.5 thous. ind. $\mathrm{m}^{-2}$ ), while at depths of 5 to $10 \mathrm{~m}$ the zoobenthos density was comparable (from 81.5 thous. ind. $\mathrm{m}^{-2}$ up to 93 thous. ind. $\mathrm{m}^{-2}$ ). Oligochaeta dominated at all sites (especially at depths of $2 \mathrm{~m}$ and $5 \mathrm{~m}$ ). They accounted for $72 \%$ to $91 \%$ of the total zoobenthos density. Chironomidae larvae (especially at a depth of $1 \mathrm{~m}-$ ca. 19\%) and Mollusca (mainly at depths of $8 \mathrm{~m}$ and $10 \mathrm{~m}$ - about 20\%) were also important groups of the bottom fauna.

In contrast to the density, clear differences in the total zoobenthos biomass between the sampling sites were found (Table 2). To a depth of $8 \mathrm{~m}$ there was a marked increase in the value of the discussed parameter (from about $300 \mathrm{~g} \mathrm{~m}^{-2}$ to about $1000 \mathrm{~g} \mathrm{~m}^{-2}$ ), while at a depth of $10 \mathrm{~m}$ the decrease in the total bottom fauna biomass (approx. 600 $\mathrm{g} \mathrm{m}^{-2}$ ) was noted. Mollusca clearly dominated at all sites. The share of this group of zoobenthos was comparable at depths of $1 \mathrm{~m}$ to $8 \mathrm{~m}$ (over $90 \%$ of the total zoobenthos biomass) and higher than at a depth of $10 \mathrm{~m}(75 \%)$. The opposite situation was found in the case of Chironomidae larvae and Oligochaeta. The share of these organisms in the total biomass of bottom fauna at a depth of $10 \mathrm{~m}$ was at least twice as high as at the other sites. However, it should be noted that Mollusca were weighed together with their shells, which contributed to the overestimation of their biomass. For this reason, the zoobenthos biomass without Mollusca was also calculated. The values of this parameter increased with the depth (Table 2) and ranged from $25 \mathrm{~g} \mathrm{~m}^{-2}(1 \mathrm{~m})$ to $154 \mathrm{~g} \mathrm{~m}^{-2}(10 \mathrm{~m})$. 


\section{Chironomidae}

Among the Chironomidae larvae, 14 taxa were distinguished. The largest taxonomic richness was found at a depth of $1 \mathrm{~m}$ (11 taxa). The number of taxa at the other sampling sites was lower and comparable (from 6 to 8 ). The Shannon diversity index values were similar at depths of $1 \mathrm{~m}$ to $8 \mathrm{~m}$ (from 1.82 to 2.11) and clearly higher than at a $10 \mathrm{~m}$ depth (1.12). The chironomid densities at depths of $1 \mathrm{~m}, 5 \mathrm{~m}, 8 \mathrm{~m}$, and $10 \mathrm{~m}$ were similar (from 3,252 ind. $\mathrm{m}^{-2}$ to 5,495 ind. $\mathrm{m}^{-2}$ ). Slightly lower values of this parameter were found at a $2 \mathrm{~m}$ depth $\left(1,990\right.$ ind. $\left.\mathrm{m}^{-2}\right)$.

Among the chironomids Chironomus sp. and Procladius sp. larvae dominated. Their share increased with the depth (together from $17 \%$ to $98 \%$ of the total chironomid density) (Fig. 2). The shallower parts of the reservoir were characterized by a higher share of taxa such as Glyptotendipes sp., Cryptochironomus sp., Dicrotendipes sp. and Cladotanytarsus sp. larvae. The latter were present only at a depth of $1 \mathrm{~m}$. Polypedylum gr. nubeculosum larvae were also relatively numerous. Their share at depths from $1 \mathrm{~m}$ to $5 \mathrm{~m}$ was similar (approx. 12\%) and nearly twice lower than at $8 \mathrm{~m}$ depth (approx. 22\%), while at a depth of $10 \mathrm{~m}$ their share was negligible.

The total chironomid biomass at depths of $1 \mathrm{~m}$ to $5 \mathrm{~m}$ were comparable (from $4 \mathrm{~g} \mathrm{~m}^{2}$ to $10 \mathrm{~g} \mathrm{~m}^{-2}$ ) and clearly lower than at depths of $8 \mathrm{~m}$ and $10 \mathrm{~m}\left(28 \mathrm{~g} \mathrm{~m}^{2}\right.$ and $64 \mathrm{~g}$ $\mathrm{m}^{-2}$, respectively).

\section{Mollusca}

The number of Mollusca taxa was similar at depths of $1 \mathrm{~m}$ to $8 \mathrm{~m} \mathrm{(8-9} \mathrm{taxa)}$ and twice smaller at a $10 \mathrm{~m}$ depth (4 taxa) (Table 1). The diversity of this group was higher at depths of $1 \mathrm{~m}$ (1.39) and $2 \mathrm{~m}$ (1.29), lower and similar at the greater depths ranging from 0.94 to 1.03 . The Mollusca density increased rapidly to a depth of $8 \mathrm{~m}$ (from 1,006 ind. $\mathrm{m}^{-2}$ to 19,402 ind. $\mathrm{m}^{-2}$ ), while at depths of $8 \mathrm{~m}$ and $10 \mathrm{~m}$ the values of this parameter were comparable (approx. 18-19 thous. ind. $\mathrm{m}^{-2}$ ).

Among Mollusca small clams Sphaerium sp. and $P i$ sidium sp. dominated. The share of Sphaerium sp. was comparable at each sampling sites and ranged from $65 \%$ to $83 \%$ of the total Mollusca density, while the share of $\mathrm{Pi}$ sidium sp. increased with depth from $1 \%$ to $34 \%$. Valvata naticina was also quite numerous, especially at depths of 5 $\mathrm{m}$ and $8 \mathrm{~m}$ as well as Viviparus viviparus mainly at depths of $1 \mathrm{~m}$ and $5 \mathrm{~m}$.

As in the case of density, the significant increase in the molluscan biomass to a depth of $8 \mathrm{~m}$ (from $282 \mathrm{~g} \mathrm{~m}^{-2}$ to $956 \mathrm{~g} \mathrm{~m}^{-2}$ ) was found. In turn, at a depth of $10 \mathrm{~m}$ the biomass was twice lower than at $8 \mathrm{~m}$ depth.

\section{Hirudinea}

The number of Hirudinea taxa was comparable at depths of $1 \mathrm{~m}$ to $8 \mathrm{~m}$ (from 4 to 6 ) and twice higher than at $10 \mathrm{~m}$

Table 1. Taxonomic composition, number of taxa and diversity, as well as average density (ind. $\mathrm{m}^{-2}$ ) of the macrozoobenthos at the particular depths of the Włocławek Dam Reservoir

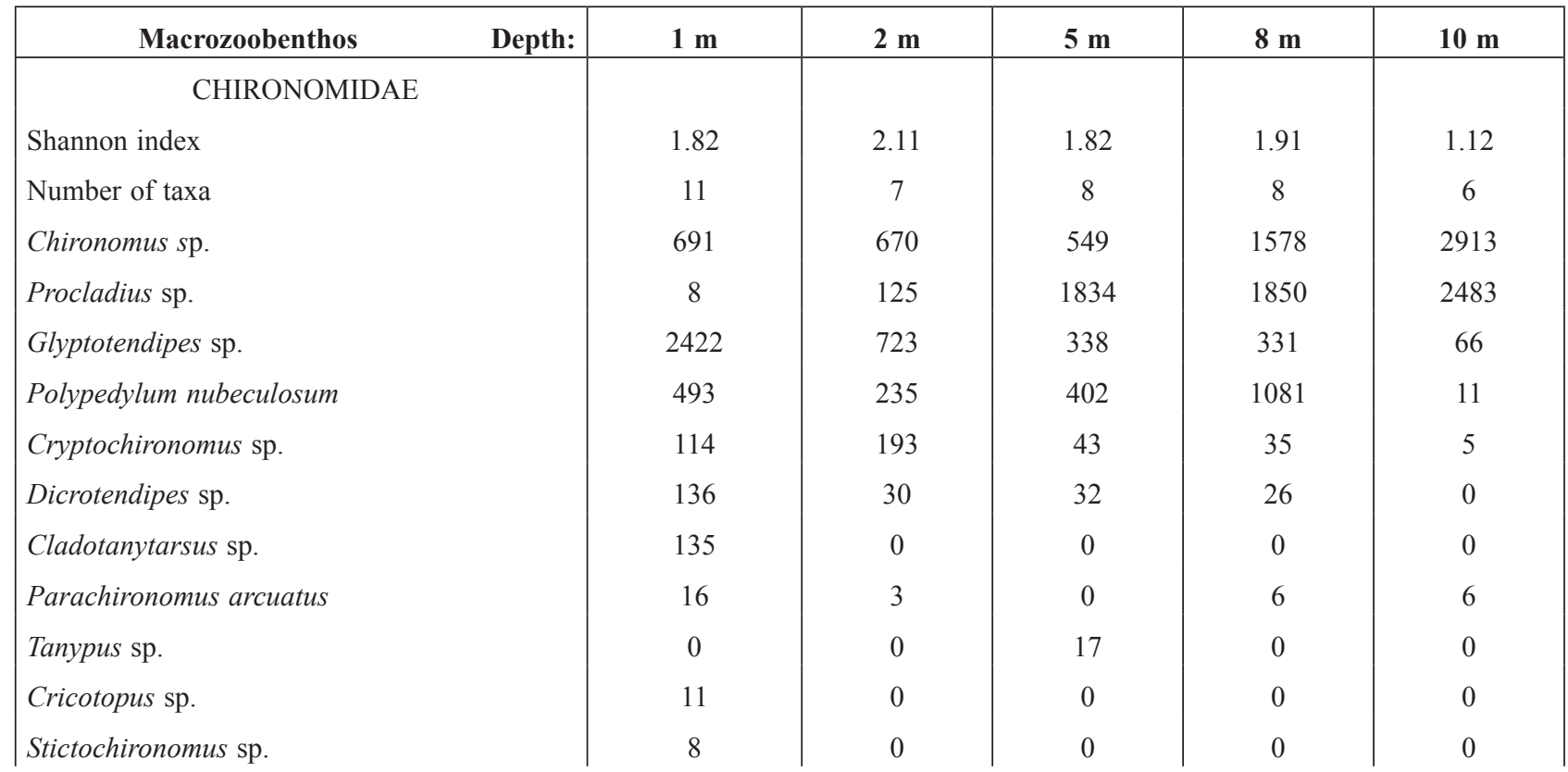




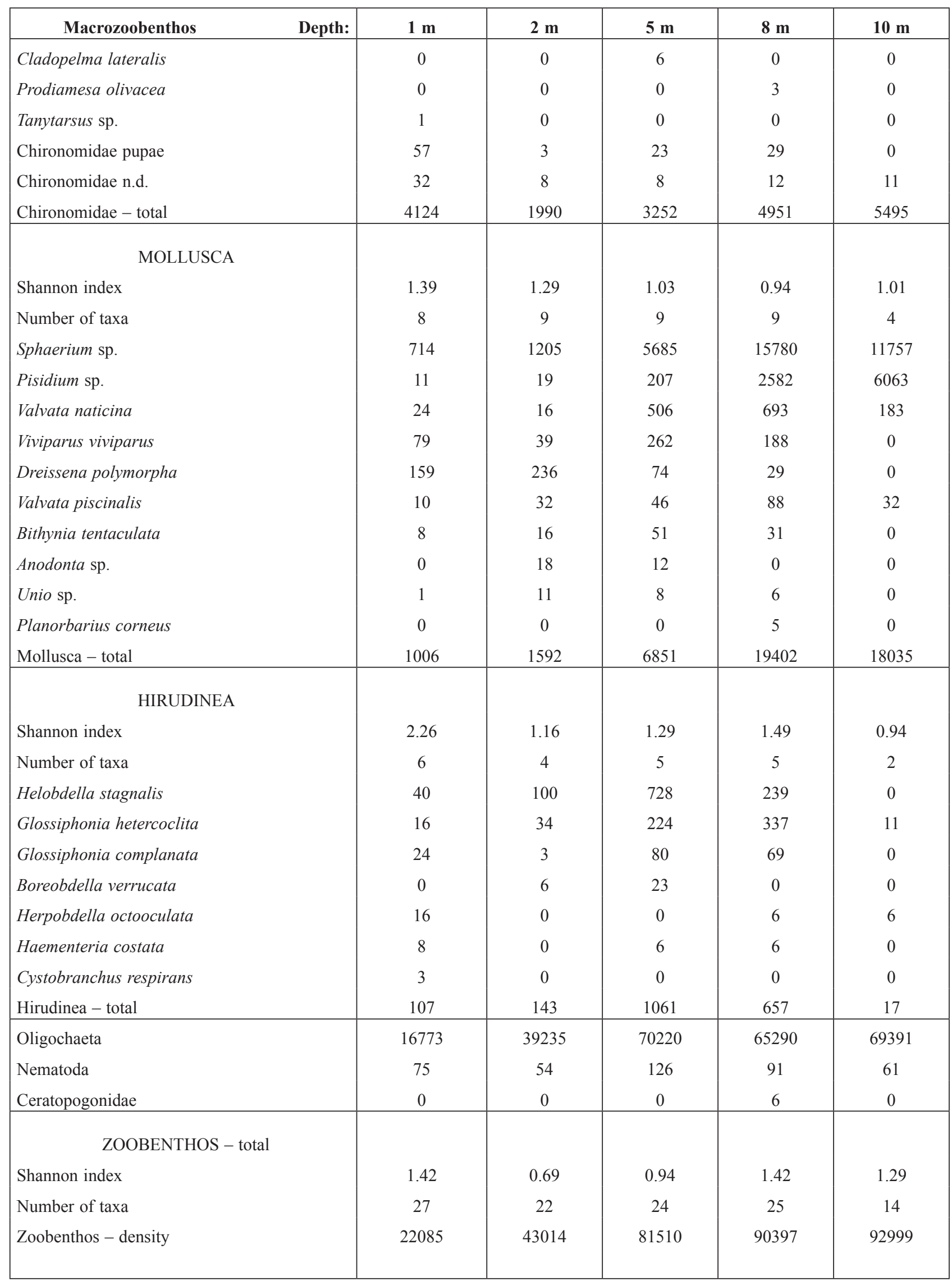


depth (2 taxa). Although the greatest diversity of this group was recorded at a depth of $1 \mathrm{~m}$ (2.26) and the lowest at a depth of $10 \mathrm{~m}$ (0.94), no close relation between this parameter and the depth was found. The Hirudinea densities were higher at depths of $5 \mathrm{~m}$ and $8 \mathrm{~m}\left(1,061\right.$ ind. $\mathrm{m}^{-2}$ and 657 ind. $\mathrm{m}^{-2}$, respectively), clearly lower and similar at depths of $1 \mathrm{~m}$ and $2 \mathrm{~m}$ (107 ind. $\mathrm{m}^{-2} ; 143$ ind. $\mathrm{m}^{-2}$, respectively) and the lowest at $10 \mathrm{~m}$ depth (only 17 ind. $\mathrm{m}^{-2}$ ).

Among Hirudinea Helobdella stagnalis and Glossiphonia heteroclita dominated. The highest share of these taxa in the total Hirudinea density at depths of $2 \mathrm{~m}, 5 \mathrm{~m}$ and $8 \mathrm{~m}$ (approx. 90\%) was recorded. Glossiphonia complanata (especially at a depth of $1 \mathrm{~m}$ - approx. 22\%) was also relatively numerous.

\section{Oligochaeta}

The Oligochaeta density was clearly higher and higher to a depth of $5 \mathrm{~m}$ (from 17 thous. to 70 thous. ind. $\mathrm{m}^{-2}$ ) while at depths of $5 \mathrm{~m}$ to $10 \mathrm{~m}$ the values of this parameter were now comparable (from 65 thous. to 70 thous ind. $\mathrm{m}^{-2}$ ). In turn, the Oligochaeta biomass increased with depth from $14 \mathrm{~g} \mathrm{~m}^{-2}(1 \mathrm{~m})$ to $89 \mathrm{~g} \mathrm{~m}^{-2}(5 \mathrm{~m})$.

To sum up, to a depth of $8 \mathrm{~m}$, the bottom fauna of the reservoir under study was relatively rich in quality. The significant decline in the diversity and, above all, the number of taxa of the macrozoobentos groups, were found only at a depth of $10 \mathrm{~m}$. In turn, the abundance (density and biomass) of the bottom fauna increased with depth of the reservoir. This parameter (especially biomass) showed clear differences between the sampling sites.

\section{Discussion}

The results of this study have shown that the macrozoobenthos was diverse and abundant even at relatively large depths. This was a consequence of the deeper occurrence of taxa sensitive to low oxygen concentration which usually inhabit only the shallow, littoral zone. One of the possible explanations could be a high water dynamics in a reservoir, providing good oxygenation of near bottom water. However, it should be stressed that most probably another important factor facilitating deeper penetration of the benthic animals was also the large inclination angle of the reservoir bottom resulting in small horizontal distances between the sampling sites and allowing to slip some benthic invertebrates down the slope.

As the depth increased, there was the increase in the organic matter content in the bottom sediments. This is a typical feature of water bodies (Kajak, 1988). The values of that parameter at the shallower depths were small probably due to the high water dynamics and, consequently, the low intensity of sedimentation processes, as well as the favorable conditions (good oxygenation) for mineralization of the organic matter at the bottom. The highest organic matter content was found in the sediments at depths of $8 \mathrm{~m}$ and $10 \mathrm{~m}$. Probably this is due to the fact that only these two sites were located in the former Vistula river bed. The values of this parameter were typical of the muddy bottom sediments of dam reservoirs (Żbikowski, 1995).

The substantial decrease in the species richness of the total bottom fauna, as well as a relatively low diversity of the analyzed zoobenthos groups were found only at a depth of $10 \mathrm{~m}$. It was probably the consequence of the deterioration of the aerobic conditions over the bottom. According to Merritt et al. (2002) even short-lived oxygen deficiencies can be effective in reducing the occurrence of less tolerant benthic animals.

The analysis of the macrozoobenthos taxonomic composition in the deeper parts of the reservoir may raise some doubts. On one hand, the dominance of Chironomus sp. and Procladius sp. larvae among Chironomidae, as well as Sphaerium sp. and Pisidium sp. among Mollusca, indicate poor habitat conditions. According to the literature data, these organisms are extremely tolerant, resistant to

Table 2. The average biomass $\left(\mathrm{g} \mathrm{m}^{-2}\right)$ of the macrozoobenthos at the particular depths of the Włocławek Dam Reservoir

\begin{tabular}{|c|c|c|c|c|c|c|}
\hline Macrozoobenthos & Depth: & $1 \mathrm{~m}$ & $2 \mathrm{~m}$ & $5 \mathrm{~m}$ & $8 \mathrm{~m}$ & $10 \mathrm{~m}$ \\
\hline Mollusca & & 282.37 & 522.40 & 783.95 & 955.47 & 463.53 \\
\hline Oligochaeta & & 14.24 & 38.18 & 54.16 & 70.43 & 89.32 \\
\hline Chironomidae & & 10.23 & 4.37 & 8.94 & 28.51 & 64.26 \\
\hline Others* & & 1.06 & 0.89 & 3.16 & 3.46 & 0.76 \\
\hline ZOOBENTHOS - total & & 307.90 & 565.84 & 850.21 & 1057.87 & 617.87 \\
\hline ZOOBENTHOS - without Mollusca & & 25.53 & 43.44 & 66.26 & 102.40 & 154.34 \\
\hline
\end{tabular}

* Hirudinea, Nematoda, Ceratopogonidae 


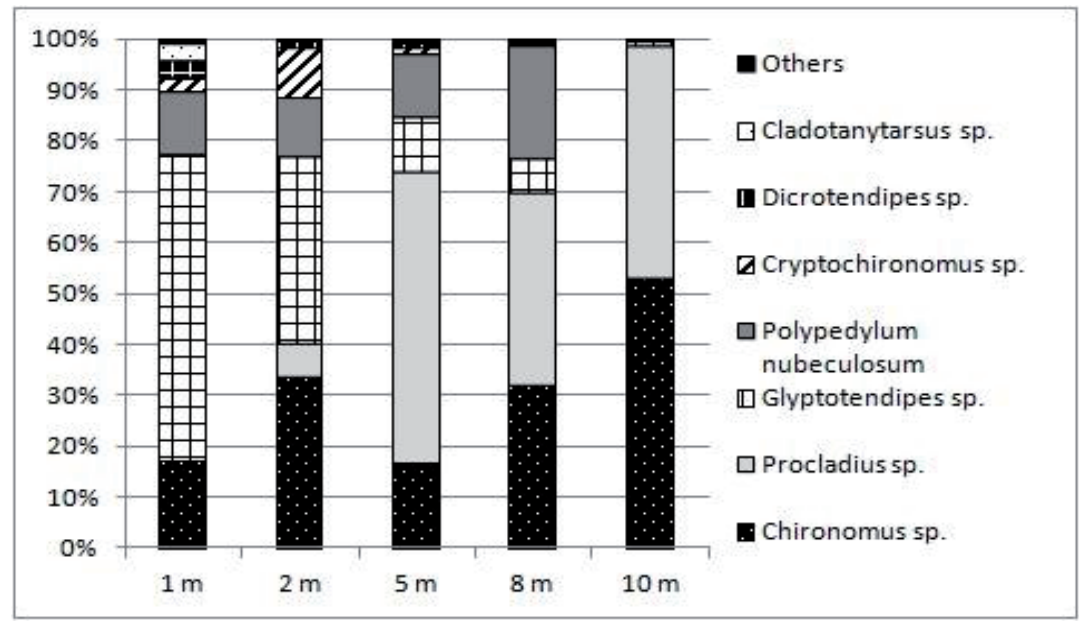

Figure 2. Percentage share of the particular taxa in the total density of Chironomidae larvae at the sampling stations

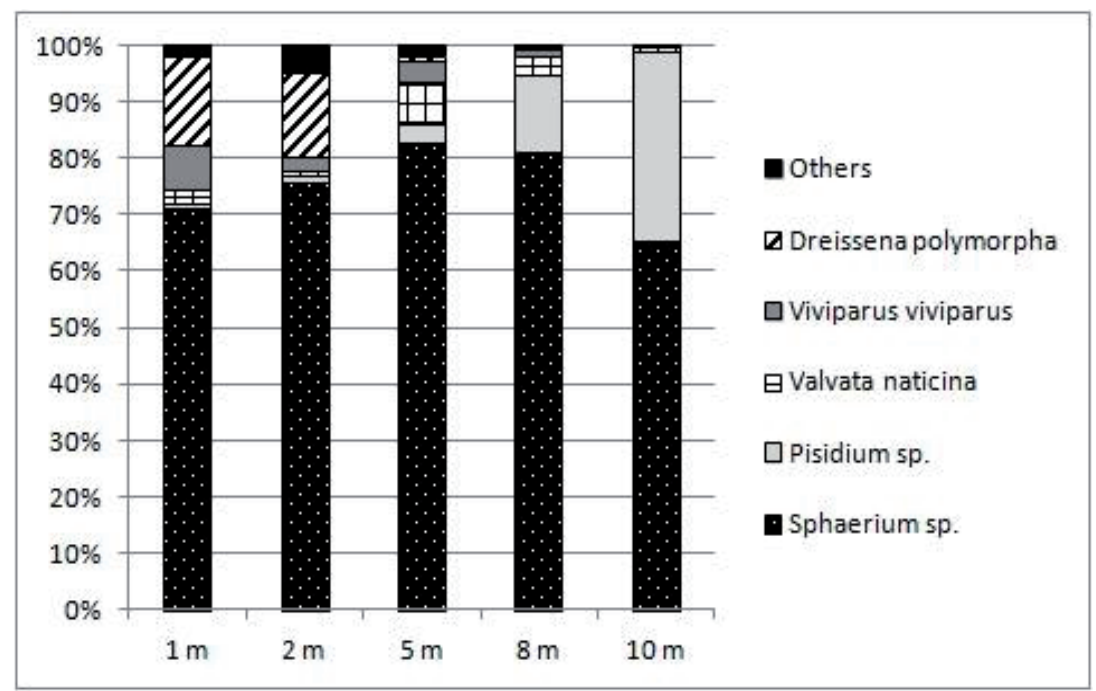

Figure 3. Percentage share of the particular taxa in the total density of Mollusca at the sampling stations

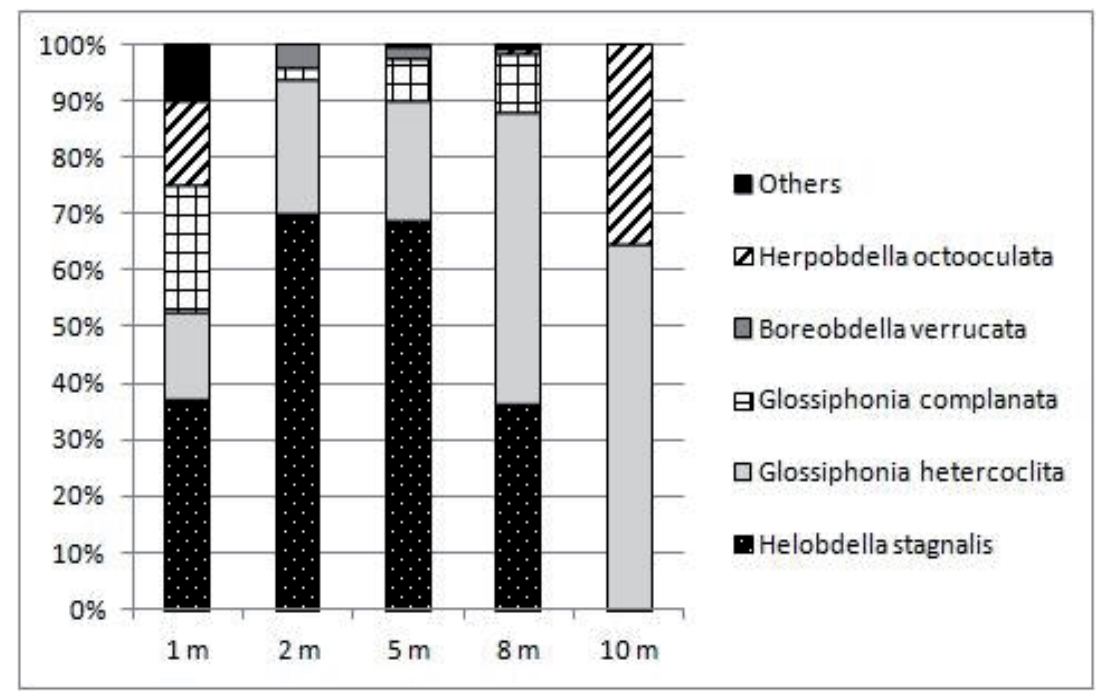

Figure 4. Percentage share of the particular taxa in the total density of Hirudinea at the sampling stations 
unfavorable environmental conditions, especially low oxygen concentration in water or presence of toxic substances (Piechocki \& Dyduch-Falniowska, 1993; Armitage et al., 1995; Nyman et al. 2005). On the other hand, at the same depths, the relatively large abundance of taxa considered to be typical of littoral zone, intolerant of low oxygen level in water, was found. This refers both to Hirudinea (especially Glossiphonia heteroclita and Helobdella stagnalis) and to Gastropoda (especially Valvata sp.). The interpretation of the above inconsistencies is not easy. Perhaps the dominance of taxa considered tolerant and resistant does not necessarily indicate very poor habitat conditions. However, another possible explanation is that sensitive species that require good water oxygenation, as a result of the increasing eutrophication of water bodies, extend the range of their tolerance and adapt to less favorable habitat conditions. The above contradictions indicate the need to continue the research aimed to investigate the relationship between benthic organisms and their habitat.

The favorable habitat conditions in the studied area of the reservoir were also confirmed by very large abundance of the macrozoobenthos. The density and biomass of the benthic fauna increased with depth. Oligochaeta dominated in this respect, which is characteristic of most dam reservoirs (Dusoge et al., 1990; Real et al., 1993; Di Giovanni et al., 1996; Shao et al., 2006; Findik, 2013; Georgieva \& Uzunov, 2015). The strong dominance of this zoobenthos group has now been recorded at depths of $1 \mathrm{~m}$ and $2 \mathrm{~m}$, which seems to be quite surprising, due to the very low organic matter content in the bottom sediments at these sites. The analysis of the horizontal increase in Oligochaeta abundance suggests that at depths of up to $5 \mathrm{~m}$, the limiting factor for their existence could be food shortage. In turn, at depths of $5 \mathrm{~m}$ to $10 \mathrm{~m}$, despite the further increase of the organic matter content in the sediments, the Oligochaeta density was similar. Therefore the results indicate that at the level of about $4 \%$ of the organic matter content in the bottom sediments, the food conditions are no longer a factor limiting the Oligochaeta occurrence.

\section{Conclusions}

As mentioned earlier, the taxonomic composition and abundance of bottom fauna depend on many environmental factors. Most researchers agree that among these factors, oxygen and food conditions are of great importance. The results of this research may suggest that the reduction in diversity and abundance of macrozoobenthos with depth, observed especially in eutrophic water bodies, is most likely due to poor oxygen conditions near bottom rather than limitation of food availability. The confirmation of this hypothesis could be the occurrence of diverse and abundant the bottom fauna at the greater depths, de- spite the relatively low organic matter content in the bottom sediments.

\section{References}

Angradi T.R., Pearson M.S., Bolgrien D.W., Jicha T.M., Taylor B.H. \& Hill D.L., 2009, Multimetric macroinvertebrate indices for mid-continent US great rivers, Journal of the North American Benthological Society 28: 785-804.

Armitage P.D., Cranston P.S. \& Pinder L.C.V., 1995, The Chironomidae biology and ecology of non-biting midges, Chapman \& Hall, London.

Behrend R.D.L., Takeda A.M., Gomes L.C. \& Fernandes S.E.P., 2012, Using oligochaeta assemblages as an indicator of environmental changes, Brazilian Journal of Biology 72 (4): 873-884.

Callisto M., Goulart M., Barbosa F.A.R. \& Rocha O., 2005, Biodiversity assessment of benthic macroinvertebrates along a reservoir cascade in the lower São Francisco river (northeastern Brazil), Brazilian Journal of Biology 65: 229-240.

Chapman P.M., Anderson B., Carr S., Engle V., Green R., Hameedi J., Harmon M., Haverland P., Hyland J., Ingersoll C., Long E., Rodgers J., Jr, Salazar M., Sibley P.K. \& Windom H., 1997, General guidelines for using the sediment quality triad, Marine Pollution Bulletin 34: $368-372$.

Ciutat A., Weber O., Gerino M. \& Boudou A., 2006, Stratigraphic effects of tubificids in freshwater sediments: a kinetic study based on X-ray images and grain-size analysis, Acta Oecologica 30(2): 228-237.

Clements W.H. \& Kiffney P.M., 1993, Assessing contaminant effects at higher levels of biological organization, Environmental Toxicology and Chemistry 13: 357-359.

Cooper C.M. \& Knight L.A., 1985, Macrobenthos - sediment relationships in Ross Barnett Reservoir, Mississippi, Hydrobiologia 126: 193-197.

Declerck S., Vandekerkhove J., Johansson L., Muylaert K., Conde-Porcuna J. M., van der Gucht K., Pérez-Martìnez C., Lauridsen T., Schwenk K., Zwart G., Rommens W., López-Ramos J., Jeppesen E., Vyverman W., Brendonck E. \& de Meester L., 2005, Multi-group biodiversity in shallow lakes along gradients of phosphorus and water plant cover, Ecology 86(7): 1905-1915.

Di Giovanni M.V., Goretti E. \& Tamanti V., 1996, Macrobenthos in Montedoglio Reservoir, central Italy, Hydrobiologia 321: 17-28.

Dos Santos N.C.L., de Santana H.S., Dias R.M., Borges H.L.F., de Melo V.F., Severi W., Gomes L.C. \& Agostinho A.A., 2016, Distribution of benthic macroinvertebrates in a tropical reservoir cascade, Hydrobiologia 765: 265-275. 
Dusoge K., Lewandowski K. \& Stańczykowska A., 1990, Liczebność i biomasa fauny dennej w różnych środowiskach Zbiornika Zegrzyńskiego [The abundance and biomass of benthic fauna in various habitats of Zegrze Dam Reservoir], [in:] Funkcjonowanie ekosystemów wodnych, ich ochrona i rekultywacja. Część I, Ekologia zbiorników zaporowych i rzek [Functioning of aquatic ecosystems, their protection and recultivation. Part I. Ecology of dam reservoirs and rivers], Z. Kajak (ed.), SGGW-AR, Warszawa: 57-85.

Findik Ö., 2013, Spatial and seasonal distribution of macroinvertebrates in high altitude reservoir (Beyler Reservoir, Turkey), Chinese Journal of Oceanology and Limnology 31(5): 994-1001.

Georgieva G. \& Uzunov Y., 2015, Macrozoobenthos diversity of two Bulgarian reservoirs accrding to some environmental parameters, International Journal of Ecosystems and Ecology Science 5(3): 293-298.

Graneli W., 1979, The influence of Chironomus plumosus larvae on the oxygen uptake of sediment, Archiv für Hydrobiology 87: 385-403.

Grześ M., 1983, Niektóre problemy stopnia wodnego "Włocławek" i jego zbiornika [Some problems of "Włocławek" barrage and its reservoir], Czasopismo Geograficzne 54: 439-457.

Hargeby A., Andersson G., Blindow I. \& Johansson S., 1994, Trophic web structure in a shallow lake during a dominance shift from phytoplankton to submerged macrophytes, Hydrobiologia 279/280: 83-90.

Hellawell J.M., 1986, Biological Indicators of Freshwater Pollution and Environmental Management, Elsevier, London.

Kajak Z., 1988, Considerations on benthos abundance in freshwaters, its factors and mechanisms, International Review of Hydrobiology 73(1): 5-19.

Kentzer A., Giziński A. \& Mieszczankin T., 1999, Hydrochemistry of the Lower Vistula River in the section Płock-Torun during the period 1986-1995: The influence of the Włocławek Dam Reservoir on water quality, Acta Univ. Nicolai Copernici, Limnological Papers 20: 13-24.

Kornijów R., Gulati R.D. \& Ozimek T., 1995, Food preference of freshwater invertebrates: comparing fresh and decomposed angiosperm and a filamentous alga, Freshwater Biology 33: 205-212.

Merritt R.W., Cummins K.W., Berg M.B., Novak J.A., Higgins M.J., Wessell K.J. \& Lessard J.L., 2002, Development and application of a macroinvertebrate functional-group approach in the bioassessment of remnant river oxbows in southwest Florida, Journal of the North American Benthological Society 21: 290-310.

Moreno P. \& Callisto M., 2006, Benthic maroinvertebrates in the watershed of an urban reservoir in southeastern Brazil, Hydrobiologia 560: 311-321.
Moss B. \& Timms M., 1989, Predation, sediment stability and food availability as determinants of the benthic invertebrate fauna in two shallow lakes, Hydrobiologia 185: 249-257.

Nyman M., Korhola A. \& Brooks S.J., 2005, The distribution and diversity of Chironomidae (Insecta: Diptera) in western Finnish Lapland, with special emphasis on shallow lakes, Global Ecology \& Biogeography 14: 137-153.

Pelletier M.C., Gold A.J., Heltshe J.F. \& Buffum H.W., 2010, A method to identify estuarine macroinvertebrate pollution indicator species in the Virginian Biogeographic Province, Ecological Indicators 10: 1037-1048.

Phipps G.L., Mattson V.R. \& Ankley G.T., 1995, Relative sensitivity of three freshwater benthic macroinvertebrates to ten contaminants, Archives of Environmental Contamination and Toxicology 28: 281-286.

Piechocki A. \& Dyduch-Falniowska A., 1993, Mięczaki (Mollusca). Małże (Bivalvia). Fauna słodkowodna Polski [Molluscs (Mollusca). Bivalves (Bivalvia). Freshwater fauna of Poland], PWN, Warszawa.

Piechocki A., 1979, Mięczaki (Mollusca). Ślimaki (Gastropoda). Fauna Słodkowodna Polski [Molluscs (Mollusca), Snails (Gastropoda). Freshwater fauna of Poland], PWN, Warszawa-Poznań.

Prat N., Real M. \& Rieradevall M., 1992, Benthos of Spanish lakes and reservoirs, Limnetica 8: 221-229.

Rasmussen J.B., 1988, Littoral zoobenthic biomass in lakes, and its relationship to physical, chemical and trophic factors, Canadian Journal of Fisheries and Aquatic Sciences 45: 1436-1447.

Real M. \& Prat N., 1991, Changes in the benthos of five Spanish reservoirs in the last 15 years, Verh. Internat. Verein. Limnol. 24: 1377-1381.

Real M., Prat N. \& Riera J.L., 1993, Abundance and distribution of profundal zoobenthos in Spanish reservoirs: differences between 1973/75 and 1987/88 surveys, Water Science and Technology 28(6): 45-53.

Reynoldson T.B., Bailey R.C., Day K.E. \& Norris R.H., 1995, Biological guidelines for freshwater sediment based on BEnthic Assessment of SedimenT (BEAST) using a multivariate approach for predicting biological state, Australian Journal of Ecology 20: 198-219.

Rodriguez P., Martinez M. M., Arrate J.A. \& Navarro E., 2001, Selective feeding by the aquatic oligochaete Tubifex tubifex (Tubificidae, Clitellata), Hydrobiologia 463: 133-140.

Scheffer M. \& Jeppesen E., 1998, Alternative stable states, [in:] The structuring role of submerged macrophytes in lakes, E. Jeppesen, M. Sondergaard, M. Sondergaard, K. Christoffersen (eds), Ecol. Studies vol. 131, Springer-Verlag, New York: 397-406.

Shao M., Xie Z., Ye L. \& Cai Q., 2006, Changes in the benthic macroinvertebrates in Xiangxi Bay following 
dam closure to form the Three Gorges Reservoir, Journal of Freshwater Ecology 21(4): 717-719.

Siegfried C.A., 1984, The benthos of a eutrophic mountain reservoir: Influence of reservoir level on community composition, abundance and production, California Fish and Game 70: 39-52.

Svensson J.M. \& Leonardson L., 1996, Effects of bioturbation by tube-dwelling chironomids larvae on oxygen uptake and denitrification in eutrophic lake sediments, Freshwater Biology 35: 289-300.

Tolkamp H.H., 1980, Organism-substrate relationship in lowland streams, Thesis Agricultural University Wageningen, The Netherlands.

Wiederholm T., 1983, Chironomidae of the Holarctic region, Keys and diagnoses, Part 1. Larvae, Entomologica Scandinavica, Supplement 19.

Wills T.C., Baker E.A., Nuhfer A.J. \& Zorn T.G., 2006, Response of the benthic macroinvertebrate community in a northern Michigan stream to reduced summer streamflows, River Reseach and Applications 22: 819-836.

Wiśniewski R. \& Planter M., 1985, Exchange of phosphorus across the sediment-water interface (with special attention to the influence of biotic factors) in several lakes of different trophic status, Verhandlungen der
Internationalen Vereinigung für Limnologie 22: 3345 3349.

Żbikowski J., 1995, Struktura populacji pelofilnego makrozoobentosu Zbiornika Włocławskiego, Praca doktorska [Population structure of pelophilous macrozoobenthos of Włocławek Dam Reservoir, Ph.D. Thesis], UMK Toruń.

Żbikowski J., Kakareko T., Poznańska M. \& Kobak J., 2007, Malacofauna of two hydrologically different habitats in the near-shore zone of the Włoclawek Dam Reservoir (Vistula River, Poland), Folia Malacologica 15 (1): 25-38.

Żytkowicz R., Błędzki L., Kentzer A., Wiśniewski R., Giziński A. \& Żbikowski J., 1990, Zbiornik Włocławski. Ekologiczna charakterystyka pierwszego zbiornika zaporowego planowanej kaskady dolnej Wisły [Włocławek Dam Reservoir. Ecological characteristics of the first dam reservoir of the planned Lower Vistula cascade], [in:] Funkcjonowanie ekosystemów wodnych, ich ochrona i rekultywacja. I. Ekologia zbiorników zaporowych i rzek [Functioning of aquatic ecosystems, their protection and recultivation. Part I. Ecology of dam reservoirs and rivers] Z. Kajak (ed.), SGGW-AR, Warszawa: 201-225. 